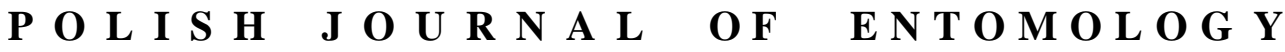

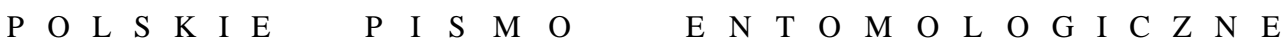

VOL. 84: 137-144

Lublin

30 September 2015

DOI: $10.1515 /$ pjen-2015-0011

\section{Mesochariodes RAZOWSKI \& WOJTUSIAK, 2006, a Neotropical Eucosmini genus, with a description of a new species (Lepidoptera: Tortricidae)}

\author{
JÓZEF RAZOWSKI ${ }^{1}$, VITOR O. BECKER ${ }^{2}$ \\ ${ }^{1}$ Institute of Systematic and Experimental Zoology, Polish Academy of Sciences, Kraków, \\ 31-016 Sławkowska 17, Poland, e-mail: Razowski@isez.pan.krakow.pl \\ ${ }^{2}$ Reserve Serra Bonita, PO Box 01, 45880 Camacan BA, Brazil, \\ e-mail: Becker.vitor@gmail.com
}

\begin{abstract}
A revision of Mesochariodes is provided with a list of known species and characteristics of Proteoteras and Acroclita. Three species are described as new: Mesochariodes armifera sp. $\mathrm{n}$., M. obrimospina sp. n., M. ochyrosetaria sp. n. Male genitalia of $M$. tablonica are redescribed.
\end{abstract}

KEY WORDS: Lepidoptera, Tortricidae, Mesochariodes, new species, Ecuador.

\section{INTRODUCTION}

Mesochariodes RAZOWSKI \& WOJTUSIAK, 2006 is an Olethreutinae, Eucosmini genus that includes two species from Venezuela. Two other species have been described by RAZOWSKI $\&$ WOJTUSIAK $(2008,2009)$. After the study of additional material from Ecuador collected by V.O. BECKER, we can now add three new species to this very characteristic genus and to give new diagnostic characters to distinguish it from the nearest related Eucosmini genera.

\section{Acknowledgements}

The authors thank Witold ZAJDA and Artur CZEKAJ, Kraków, for taking the photographs and arranging the plates. 


\section{MATERIAL}

All the specimens were collected by the junior author in Ecuador. The types of the newly described species have been temporarily deposited in the BECKER Collection, Camacan, Brazil, and will eventually be housed in one of the Brazilian museums. A few specimens have been donated to the Institute of Systematics and Evolution of Animals, PAS, Kraków.

Abbreviations used: GS - genitalia slide, WZ - Witold ZAJDA.

\section{SYSTEMATIC PART}

Mesochariodes RAZOWSKI \& WOJTUSIAK, 2006

\section{Diagnosis}

In the male genitalia the uncus is broadly fused with the tegumen and forms a broad apical lobe with lateral sclerotized projections which may be armed with additional, lateral thorns or spines. The socius consists of two parts, a more or less long proximal one, and a distal, rather flat one, which may be simple or armed with processes or setae. The pulvinus is ill-defined; the ventral edge of the valva is usually armed with strong setae.

Originally Mesochariodes was compared to Mesocharis DIAKONOFF, 1981. The following is a comparison with two further genera.

Proteoteras RILEY, 1881 is represented by eight North American species and one Neotropical species (P. atromacula RAZOWSKI \& LANDRY, 2008, Galapagos). The males have modified scaling forming a subcostal hindwing scent organ, absent in Mesochariodes. In the male genitalia the uncus is almost completely reduced, the socii are rather well sclerotized, and the valva is armed with strong outer and/or ventral spines, but Proteoteras mainly differs from Mesochariodes in the lack of a pulvinus and a long sterigma situated in a deep incision of the subgenital sternite, and in the absence of transverse rib.

In the female genitalia the sterigma is elongate, situated in and fused with a deep incision of the subgenital sternite with an anterior, transverse rib marked with a pair of submedian thorns.

Acroclita LEDERER, 1859 is known mainly from southern Europe and Asia. HORAK (2006) included in this genus the Australian Hylotropha bryopa MEYRICK, 1911, which differs, however, from A. subsequana (HERRICH-SCHÄFFER, 1851) from SW Europe, especially in the shape and position of the uncus and socii (the scent organs are similar in the two genera). H. bryopa has bifid, weakly sclerotized socii similar to Mesochariodes, but like A. subsequana has no pollex and has a simple subgenital sternite. 


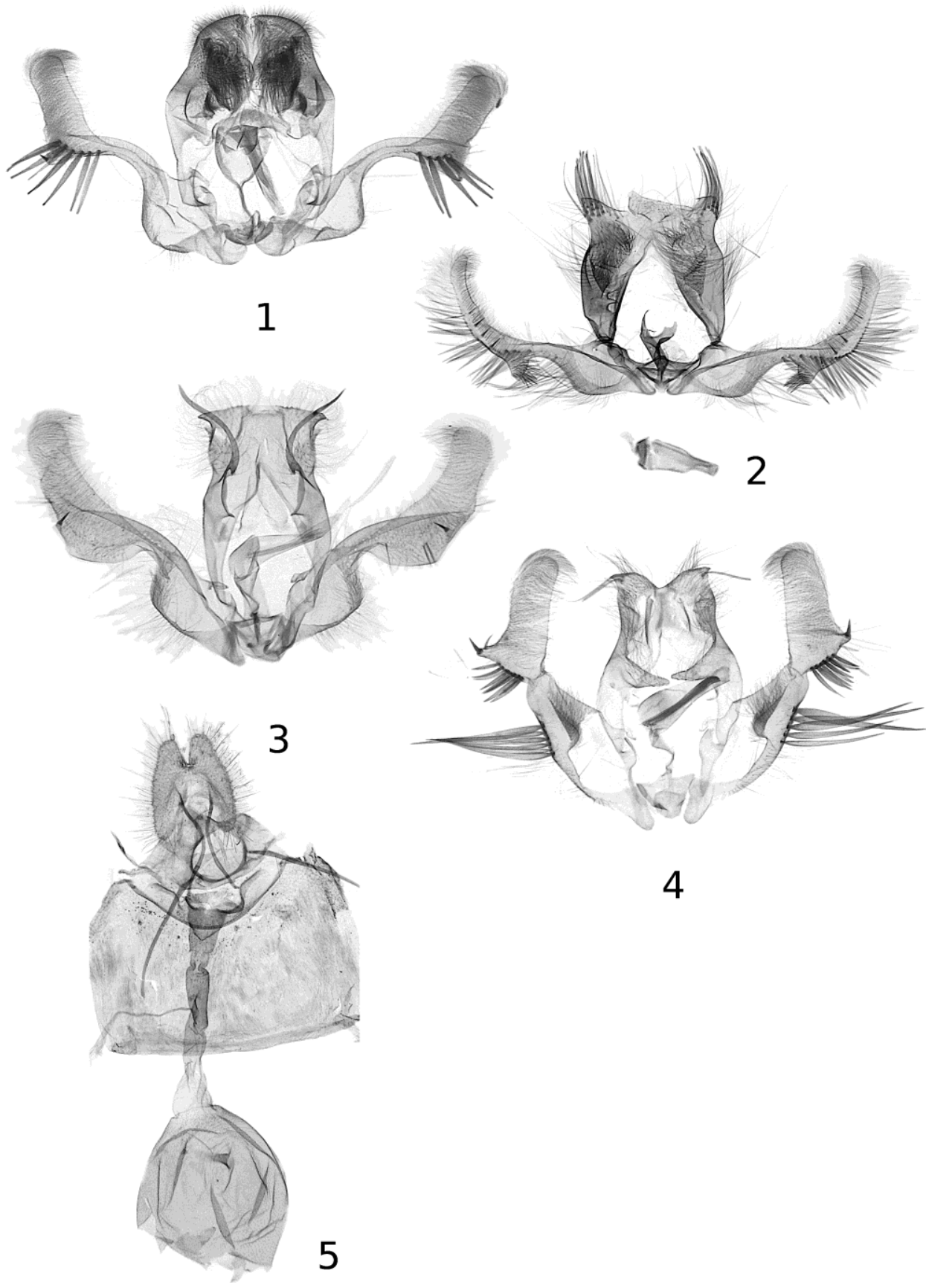

Figs 1-5. Male and female genitalia: 1 - Mesochariodes armifera sp. n., holotype; 2 - M. tablonica RAZOWSKI \& WOJTUSIAK, 2006, Tungurahua, Ecuador; 3 - M. obrimospina sp. n., holotype; $4-$ M. ochyrosetaria sp. n., holotype. 


\section{List of Mesochariodes species}

- M. armifera sp. n., male and female genitalia; Ecuador: Loja Province.

- M. micropollex RAZOWSKI \& WOJTUSIAK 2008 (Mesotrichodes), male genitalia; Ecuador: Zamora-Chinchipe Province.

- M. obrimospina sp. n., male genitalia; Ecuador: Loja Province.

- M. ochyrosetaria sp. n., male genitalia; Ecuador: Pastaza Province.

- M. polytrichota RAZOWSKI \& WOJTUSIAK, 2006, male and female genitalia; Venezuela.

- M. secunda RAZOWSKI \& WOJTUSIAK, 2006 (Mesotrichodes), female genitalia; Venezuela.

- M. tablonica RAZOWSKI \& WOJTUSIAK, 2009 (Mesotrichodes), male genitalia; Ecuador: Tungurahua Province.

\section{Mesochariodes armifera sp. $\mathbf{n}$.}

\section{Diagnosis}

(Figs 1, 2, 6)

The facies of M. armifera is similar to that of M. secunda (Fig. 42 on page 58 in RAZOWSKI $\&$ WOJTUSIAK 2006) but it has a paler, brownish cream, forewing dorsum. The male genitalia are as in M. tablonica (Fig 11 on page 163 in RAZOWSKI \& WOJTUSIAK), but in M. armifera the uncus is broadly rounded and aedeagus long, slender. The female genitalia are similar to $M$. secunda (Fig. 117 in RAZOWSKI \& WOJTUSIAK 2006), but in M. armifera the posterior lobes of sterigma are directed distad, the sclerite of the antrum tapers proximally, and the lobes of subgenital sternite are slenderer.

\section{Description}

Wing span $21 \mathrm{~mm}$. Head and thorax brownish cream; median joint of labial palpus with weak brownish grey marking, base of tegula tinged brown. Forewing somewhat expanding terminad; termen slightly concave beneath apex, then bent. Ground colour cream present along dorsum and medioposteriorly, in other parts of wing mixed ferruginous; costal strigulae mostly creamish, divisions brownish and rust brown; ocellus dark cream, median spots minute, blackish; lines silver; silver spot beneath tornal blotch which is ferruginous black spotted. Markings indistinct, rust brown; dorsal longitudinal markings typical, browner than transverse elements. Cilia cream with brown interruptions and basal line. Hindwing whitish cream in costal half slightly tinged brownish grey; subcostal scent organ rather short with broad brown surrounding area in basal half of wing; cilia cream, in apical part yellower.

Variation. Paratype forewing ground colour cream tinged yellow, sprinkled blackish, extending along costa and in almost entire terminal area; remaining area brownish cream with ferruginous remnants of markings and suffusions (some of them and tornal blotch marked black). 


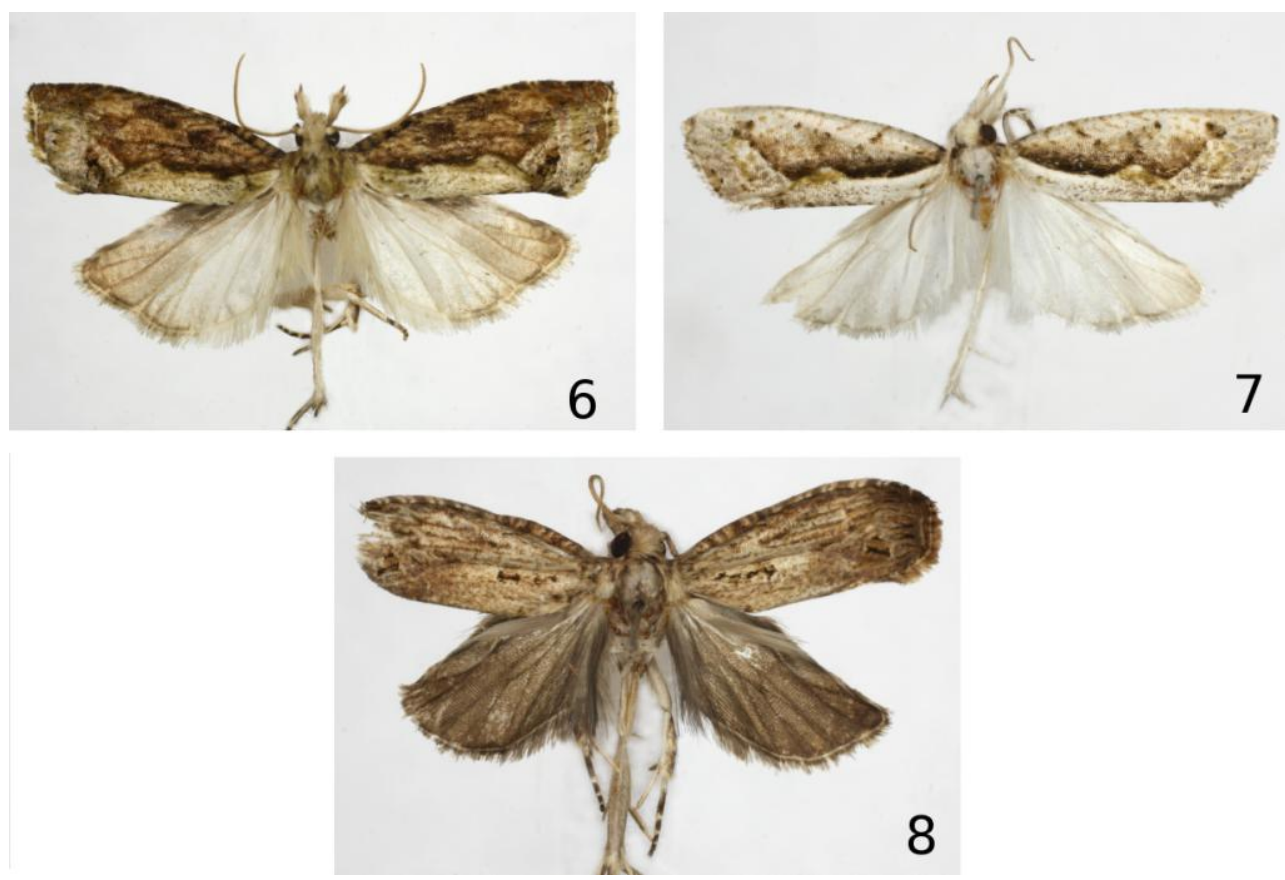

Figs 6-8. Adults: 6 - Mesochariodes armifera sp. n., holotype; 7 - M. obrimospina sp. n., holotype; $8-M$. ochyrosetaria sp. n., holotype.

Male genitalia (Fig. 1). Uncus broad, hairy, rounded posteriorly with small thorn at base of socius; the latter broad, densely setose; neck of valva long, slender with a series of six (seven in left valva) strong outer spines extending to base of cucullus; cucullus ventro-proximal; aedeagus long, slender; cornuti long.

Female genitalia (Fig. 5). Sclerite limiting the ostium area large, rounded; lateral lobes of sterigma broad; sclerite of antrum broad, triangular proximally; antrum connected to lateral lobes extending from subgenital sterite by means of slender sclerites; cingulum well developed, median; one large and one very small signum present.

\section{Material}

Holotype male: "Ecuador: Loja [Province], Loja, 2750 m, 21. XII. 1992; V.O. BECKER; Col BECKER 103163”; GS 821 WZ; paratype female, same label data, GS 822 WZ.

\section{Etymology}

The specific name refers to the series of strong spines of the valva; Latin: arma - a weapon, fere - I carry. 


\section{Mesotrichodes tablonica RAZOWSKI \& WOJTUSIAK, 2009}

(Fig. 2)

\section{Description}

Male genitalia (Fig. 2). Uncus short, broad, with posterior corners large, provided with numerous long setae; socius consisting of two broad hairy lobes; valva slender with distinct neck posteriorly limited by elongate, setose ventral lobe of cucullus; cucullus slender, long with a few (2-4) submarginal spines and dense row of marginal spines which continue proximad as far as the middle of neck of valva; sacculus angulate; aedeagus short, broad to middle, rather weakly sclerotized posteriorly; cornuti not found.

\section{Material examined}

One male from Ecuador, "Tungurahua [Province], Patate, 3000 m, 7. XII. 1992; V.O. BECKER Col BECKER 100115”; GS 147 WZ.

\section{Remarks}

This species was described from a single male collected in the same province of Ecuador, in a locality at an altitude of $3000 \mathrm{~m}$. The holotype male genitalia differ from the present specimen (described above) in that they lack the series of strong setae on the valva.

\section{Mesochariodes obrimospina sp. $\mathbf{n}$.}

(Figs 3, 7)

\section{Diagnosis}

The facies of $M$. obrimospina (Fig. 7) resembles that of M. polytrichota (Fig. 41 in RAZOWSKI \& WOJTUSIAK 2006), but this species has a distinct black-brown, straight fascia along the cubital arm of the median cell. The male genitalia of $M$. obrimospina are closely related to M. micropollex (Fig. 49 in RAZOWSKI \& WOJTUSIAK 2008), as the shape of valva shows, but the socius in obrimospina bears a very large spine, which is absent in the latter and in other congeners.

\section{Description}

Wing span $17 \mathrm{~mm}$. Head and thorax white, labial palpus long (over 5 times longer than eye diameter) with some brown dots on median joint; base of tegula brownish. Forewing slender, weakly expanding terminally; costa weakly convex; termen rather straight, slightly oblique. Ground colour white, finely dotted, and partially suffused brown; brownish dots in distal area; costal divisions small, brownish; ocellus reduced to ochreous lines and greyish median field. Markings: black-brown fascia from base of wing concave, postmedially with yellowish 
suffusion, cubital part of median cell suffused brownish; oblique line parallel to termen from end of radial fascia; three brown spots subcostally. Cilia brownish with some white interruptions. Hindwing white, slightly tinged brownish terminally; subcostal bunch of scales white.

Male genitalia (Fig. 3). Uncus very broad with two lateral thorns, postmedian and terminal; distal part of socius hairy, proximal part reduced to a sharp process extending posterad to the former, a very large, bent spine at the junction of the two parts; ventral incision of valva deep followed by broad ventral lobe of cucullus marked by three slender spines; pollex subventral; sacculus angulate; aedeagus moderate, simple; cornuti long.

Female not known.

\section{Material}

Holotype male: "Ecuador: Loja [Province], Loja, 2750 m, 21. XII. 192, V.O. BECKER; Col BECKER 103162”; GS 807 WZ.

\section{Etymology}

The name refers to the spine of the socius; Greek: obrimos - strong.

\section{Mesochariodes ochyrosetaria sp. $\mathbf{n}$.}

(Fig. 4, 8)

\section{Diagnosis}

M. ochyrosetaria is closely related to M. micropollex and M. tablonica in that it has similar lateroterminal thorns of uncus, a distinct, hairy proximal part of the socius and a row of spines beyond the ventral incision of the valva; however, it shows a row of long setae along the sacculus that is not present in its closest congeners.

\section{Description}

Wing span $14 \mathrm{~mm}$. Head and thorax cream with brownish grey admixture. Forewing not expanding terminally; costa weakly, gradually convex; termen rather straight. Ground colour pale brownish suffused and diffusely spotted brownish, paler posteriorly; brown lines along posterior, radial and first median lines; ocellus with whitish posterior lone, limiting a few brown perpendicular lines; inner spots of ocellus in form of two elongate black marks. Markings reduced to two black subdorsal marks in basal area. Cilia concolorous with suffusions. Hindwing grey brown; cilia similar; large tuft of long whitish scales from base of subcostal vein.

Male genitalia (Fig. 4). Uncus with lateroterminal thorn and distinct median concavity of distal edge; two long setae near base of the thorn present; posterior part of socius broad, 
proximal part long, tapering terminad, both hairy; ventral incision of valva weak but neck slender; sacculus weak with a group of five very strong marginal setae, a row of eight much shorter spines at the ventral lobe of cucullus; pollex subventral; aedeagus fairly short; cornuti long.

Female not known.

\section{Material}

Holotype male: "Ecuador Past[aza Province], Mera, 1300 m, VII. 1992; V. O. BECKER Col BECKER 103162"; GS 1295 WZ.

\section{Etymology}

The specific name refers to the setae of valva; Greek: ochyros - strong.

\section{REFERENCES}

HORAK M. 2006. Monographs on Australian Lepidoptera Series 10. Olethreutine moths of Australia (Lepidoptera: Tortricidae). CSIRO, Canberra.

RAZOWSKi J., WoJTUsiak, J., 2006. Tortricidae from Venezuela (Lepidoptera: Tortricidae). SHILAP Revista de Lepidopterologia 34(133): 35-79.

RAzowski J., WoJTusiak, J., 2008. Tortricidae (Lepidoptera) from the mountains of Ecuador. Part 1: Southern Highlands. Acta zoologica cracoviensia 51B(1-2): 7-41.

RAZOWSKI J., WOJTUSIAK, J., 2009. Tortricidae (Lepidoptera) from the mountains of Ecuador and remarks on their geographical distribution. Part 4: Eastern Cordillera. Acta zoologica cracoviensia., 51B(1-2): 119-187.

Received: 1 June 2015

Accepted: 23 June 2015 